\begin{tabular}{|c|c|c|}
\hline & JSM (9) (1) & \\
\hline & JURNAL SENI MUSIK & \\
\hline & https://journal.unnes.ac.id/sju/index.php/jsm/index & \\
\hline
\end{tabular}

\title{
PERSTUDE LAHAP: AN ALTERNATIVE OF VIOLIN EFFECTIVE LEARNING
} \author{
Salatiga, Indonesia \\ Info Article \\ Received : December \\ 2020 \\ Approved March 2020 \\ Publised June 2020

\section{Keywords:} \\ violin lesson; Perstude \\ Lahap method; effective \\ violin playing method
}

Leo Agung Rupiyono ${ }^{\bowtie}$

Department of Music, Faculty of Languange and Arts, Universitas Kristen Satya Wacana

Abstrak

Tujuan dari tulisan ini untuk mendeskripsikan hasil penelitian yang berkaitan dengan pembelajaran biola pada Program Studi Seni Musik Fakultas Bahasa dan Seni UKSW Salatiga. Permasalahan yang dikaji meliputi: 1) kendala-kendala yang dihadapi dalam mempelajari biola, dan 2) bagaimana menentukan metode yang tepat bagi pembelajar biola. Metode yang digunakan dalam penelitian adalah "Research and Development" (penelitian dan pengembangan). Metode ini bertujuan untuk melihat efektifitas dari metode biola "Perstude Lahap (persiapan atau pemanasan; etude atau latihan; lagu atau repertoar; dan menghafal)" yang diterapkan bagi pembelajar. Berdasarkan hasil penelitian, pembelajaran instrumen biola dapat berhasil dengan baik bila pembelajar memiliki daya tangkap atau inteligensi yang baik, motivasi yang kuat, konsistensi berlatih yang terjaga, serta menggunakan metode permainan yang tepat. Metode "Perstude Lahap" merupakan salah satu alternatif yang efektif untuk digunakan bagi pembelajar karena dapat mengajarkan pola latihan yang terstruktur dan memacu pembelajar untuk lebih mengembangkan diri secara maksimal baik secara kognitif maupun motorik.

Abstract

This article is to describe a research result of violin lesson conduct in Music Art Study Program, Faculty of Language and Arts, UKSW, Salatiga. The research problems are 1) obstructions in learning violin instrument, and 2) finding the right method for the violin learners. It is a Research and Development study aiming to find the effectiveness of the violin learning method named "Perstude Lahap". The name stands for Persiapan (preparation or warming up), Etude (practicing), Lagu (song or repertoar), and Menghapal (memorizing). The research shows that it is able to make lesson successful under the requirements that the learners are fast learners or have good intelligence, strongly motivated, persistent, and incorporating right playing method. Perstude Lahap method is one of the effective alternatives for learners as it provides wellstructured practice and stimulates learners to optimally develop both their cognitive and motoric skill.

(C) 2020 Universitas Negeri Semarang

Email : 1.Leo.rupivono@uksw.edu
} 


\section{INTRODUCING}

The rising generation as successor nation has an important role to carry on human life. They are expected to have both academic, spiritual, emotional, and social qualities so that they can prepare a good order of life. Yet, multimodern and instant living sometimes present complex problems for parents and teachers in duty and responsibility to educate them. A growing world requires both parents and teachers to develop the approaches used in educating and shaping the character of youth.

Parents and teachers are required to encourage and prepare children as students to be creative learners, which is equip them with creative thingking skills and motoric. To recognize each child's talent as a student, then to build and develop them is the duty and responsibility of parents and teachers. A child's ability and performance are the result of a combination of congenital factors and environmental factors that enable a child to develop hos talents optimally.

Music education is believed to be one of the media that can be used to educate and mold children. Regarding this, based on Peter (Fletcher, 1987) music is called educational music if the music can provide an effect that educates or humanizes children.

Through music, children can learn many things that have the potential to shape and develop characters. For example, children who learn music will be able to discern when they are soloist and when they are accompanist. Thus, in an indirect wan in their daily lives they may be able to set themselves up as exemplary leader and men who support their leader. This is exactly what is needed in today's children's education.

Music education in Indonesia actually has very much potential to develop. But in reality, there are still a few obstacles such as education system, curriculum, learning methods, teachers, facilities and financing. Among the above problems, the method of learning is one aspect that must be corrected immediately because it is substantial in the successof music education. Instrument learning is one important part of music education. An important part of this must be addressed is the methods of learning and learning material used. Learning methods are understood as knowledge of the teaching methods used by a teacher or instructor to students to achieve learning objectives (Ahmadi, 2013). Thus, proper learning methods will determine maximum result, otherwise inaccurate ones, and the maximum yield is reduced.
Whereas the learning materials are systematic set of learning materials, displaying the intact form of the competence that learner will master in the learning activities. The overall success of learning depends upon the teacher's success in designing the learning materials. To support that, the materials used should be totally contextual and close to learners. When compiling learning materials, teachers are expexted to incorporate their ideas and programs by considering their potential environment. Ideas and study programs should be based on preexisting teaching material. Knowing both the obscenity and the lack of teaching materials, the development of learning materials must pay attention to the potential of learners, relevance, characteristics, levels of physical, intellectual, emotional, social, and spiritual development of learners. The benefits, qualities, depth, and breadth of learning materials must also be relevant to the needs of learners.

One of the lessons of musical instrument that society currently enjoys is violin. Violin is one of musical instruments in which the sound production is preduce through thumped strings using biw or picked with the thumb or index finger to achieve certain effects. Violin has four strings (G-D-A-E) tuned in differently one after the other in quin interval. Violin have various roles in music. In the symphony orchestras, violin plays a backbone. As well as that, it can be played solos wheter by accompaniment or not, or it can collaborate with other musical instruments in a duet, trio, quartet, musical ensemble, and so on.

Related to that, a common problem for learners often arises when relating to the violin: how to produce the right voice, get the right intonation, play the repertoire according to the tempo their creator wants, and how to make an appropriate interpretation of a piece of music for the violin. In addition, there are still many factors affecting learners that are causing the results to be unexpected.

From the issues above the author as an educator and a violin instructor are attracted to examining violin methods of learning that are effective for learners. The study is conducted in 4 months from Septembre 2019 to December 2019 in Music Study Program, Faculty of Language and Arts, Satya Wacana Christian University Salatiga.

\section{MATERIAL AND METHOD}

The research method used in this study is reaserach and development $(R \& D)$ to sort out a 
new matter based on research. Research and development model is "a process used develop and validate educational products" which means a process used to develop and validate an educational product (Borg, 2013). In addition to developing and implementing educational outcomes, reseach and development are bridges between educational research and practical education. To find knowledge or new things through basic research or answer specific question about practical matters used to improve the quality of educational practices.

This study is intended to find appropriate methods for violin learners in order to play the violin well. In addition to that, this study focuses on current violin learning method, obstacles that the violin learner faces, and appropriate learning methods for violin learner.

The research subject was the students who took a major first-degree violin coursework in Music Study Program, Faculty of Language and Arts, Satya Wacana Christian University Salatiga.

This study is made up several stages. The first stage is a preliminary study. At this stage the researcher conducts in-depth interviews to find out the background of the violin learning processes that students obtain before going to college. What obstacles are encountered in the study of the violin, as well as what method have been used over the years. Researcher also do library studies relating to existing methods, especially to know the strengths and weaknesses of each method used.

Violin learning methods analyzed by the writer include the Suzuki dan Tuned A Day learning method. The Suzuki method is often referred to as talent education, a learning method that uses the "mother tongue" learning approach. This method believes that real talent can be "created" through a natural learning process (Suzuki, 1983). In learning music, learners has to follow a systematic technical step: 1) listening to music, 2) singing or emulating, 3) repeating the music that is heard constantly, 4) and refining it. Excess of this method, the use of familiar song materials can foster an interest for children in enthusiastic violin study. This method is appropriately used for elementary violin learners. While the weaknesses of this method are, both learner and teacher only practice and duplicate according to the instructions in both the guide book and the recordings already provided cause learners to simply imitate what is already there and are not accustomed to exploring music's works more deeply to stimulate his creativity. In addition, Suzuki's method was more stressed on composition and was less exploring both etude and violin techniques.

Unlike the Suzuki method, the next method analyzed by researcher is "Tuned A Day". Excess of this method, learning materials give more focus to producing good violin sound through short etude. Thus, learners are able to produce violing sound well and not feel dull during training. While the weakness of this methid, being focused only on the etude, the portion of the repertoire of music like sonata, both suita and concerto was limited.

The second stage done by researchers is to formulate appropriate methods for learners based on interviews and library studies. At this stage the writer prepared a method of study under the title "Perstude Lahap Method." This method emphasizes the structured exercises that students can use every day.

The third stage is implementing The Pesrtude Lahap Method. At this stage researchers applied The Perstude Lahap Method to the students who took the first major violin instrument practice as a research subject. Previously researchers conducted a preliminary test to identify the level of skill involved in the student's production of sound and playing a prepared repertoire. Researchers thereafter taught a method of learning that had been devised for about 12 weeks. In the process of executing, researchers are applying and reviewing the strengths and weaknesses of each student so that they can effectively implement The Perstude Lahap Method.

The next stage is to create a research report. At this stage researchers compile a report after getting constructive input, both from students who become objects of research and from violin teachers who offer input on how Perstude Lahap's methods of study became more interesting and effective.

\section{RESULT AND DISCUSSION \\ Current Violin Learning Barrier Factors "Perstude Lahap" Violin Method}

Muhibbin (2007: 109) defines learning as a learning process. The process comes from the Latin "processus" which means "walking forward". The process means the way or step taken to bring about several changes to achieve the desired goal. It has a connotation of a course of step or progress that leads to an objective or purpose. From differing opinions on the meaning of learning, some educationists have concluded that study is a process 
of effort by individuals to obtain a change in relative upright conduct, both observed and direct, that occurs as a result of an exercise or experience in its interactions with the environment.

Violin studies that occur today in general in Indonesia are not maximum. The lack of maximum for violin learning is caused by several factors from both the teacher and the student side. We found a lack of qualified violin teachers. While from the student's side, we find some factors that cause violin learning to be less maximum such as: interest, motivation, exercise methods, knowledge of music, and a supportive environment.

Teachers play a vital role in determining a student's success. Violin teachers must be able to prepare the material and select the proper method for each student. Many violin teachers are lacking in the techniques used in violin playing as well as musical insights. Part of it was for economic gain that forced themselves to stay teaching, indirectly making the fatal mistake of teaching the violin.

Studies conducted with students who majoring Music Study Program at Satya Wacana Christian University Salatiga that took the first major violin practice coursework, showed that there are several factors that have been impede violin studies over the years, such as: a) varying student responses, b) lack of students' motivation for violin study, c) consistency in violin learning, and d) inadequate learning methods with students.

The first factor is intelligence or intellect. Intelligent has a big influence on the violin's progress. In the same situation students who have high intelligence levels are more likely to succeed than those with low intelligence levels. But not all students who have high intelligence levels do so because there are other contributing factors. This is because learning is a complex process with factors influencing it, and intelligence is just one of the few factors. According Bischor intelligence is the ability to solve all kinds of problems. Besides intelligence, another factor that hinders students from learning violin is motivation (Psikologi, 2018).

Motivation is a force or factor within humans that generates, directs, and organizes behavior. A learner with strong motivation will be energetic. While less motivated learners will feel lazy and reluctant to complete a task. Motivasi menurut Mc. Donald (Djamarah, 2008) is a change in energy in someone's person that is marked by the emergence of affective (feelings) and reactions to achieve goals.
Motivation is closely related to the goal to be achieved. The function of motivation is to generate, base, direct, and influence the efforts, activities, and actions of a person in order to achieve the desired goal.

Motivation in learning musical instruments for students becomes an essential thing that must always be instilled in learners. With motivation, students have clear goals and direction to reach. According to Grace Soedargo, violin-teaching experts, musician may be identified as three types: 1) amateur musician, 2) regular player, and 3) artist. The lowest kind of musician is amateur. Amateur musician is poorly skilled musicians, both in technique and in knowledge, they just play music at random. The next type of musician is regular player. Musician of this type is musicians who are technically able to play music well but are lacking in creative knowledge and ideas so that they just become regular players. While the best musician to follow is artist. This type of musicians played music very well, both in technical terms and in musical terms.

Research shows that some students are just passing out as ordinary players. Students do not do maximum exploration of both technical and musical knowledge. They were in the middle of doing what their teachers told them to do, and were not yet able to develop themselves to the full.

A further factor that hinders the development of learning that students encounter is consistency in the practice of the violin. Most students have not been practicing violins regularly every day. On the average, they cannot get regular exercise, since there are many other tasks to be done. They have trouble managing their time well, resulting in not being able to practice the violin consistently. In addition, researcher have also discovered other causes, the lack of clear goals in practice. As a result, even if they practice for a long time, it will be ineffective and not maximum

\section{"Perstude Lahap" Violin Learning Method}

Perstude Lahap Violin Learning Methods is a method of learning that violin learners can use as alternatives to get the maximum results. The method focuses on how the learner exercises the violin effectively in accordance with existing stages. The method of perstusion provides ample opportunity and freedom for both teachers and learners to determine the material and target to be reached. 
The method of Perstude Lahap is a short of the training range that violin learners must be put to practice. This method is a step that violin learners must pass through and be done sequentially. These stages include: 1) preparation or heating, 2) etude or technical exercise, 3) song or repertoire, and 4) memorization.

The first stage for a violinist to go through is preparation or heating. Preparation means that learners must be able to play the scales correctly in order to produce good timbre, correct intonation, effective fingering, and maximum speed.

The difficulty that learners often encounter in violin practice is inadequate to produce sound properly with the right intonation. The technique of producing sound in a violin is very important because if the bow friction is instraight or precision then the sound it produces is loud. Whereas if the left hand's finger is incorrectly pressed on the fingerboard then the tone produced does not sound quite in tune. Thus producing a good sound requires constant friction and proper fingering. Usually during the time of friction training, learners will feel bored and saturated because they do not play the melody at all before they actually get good sound production.

With the method of Perstude Lahap, learners practice long friction but use the scale adapted to the needs of learners. Learners not only focus on upright friction and voice production, but also must pay attention to the correct intervals of tones by participating in a silent sing. Learners must be able to recognize the pitch intervals from both major and minor chords and arpegio steps of each tone that are played. The scale in the practice included the major, original minor, harmonious minor, and melodic minor. While arpegio trained include major tonica, minor tonica, first inversion of minor tonica, major subdominant, minor subdominant, diminish, dominant septime.

By practicing regularly, the muscles of the right hand and the left, including the shoulders, elbows, wrists, and fingers would be increasingly relaxed but strong enough to help in the comfort of the violin.

After learners practice the scales to produce good sound production, proper intonation, and proper fingering then the next step is to create a variety of rhythms and vibrations to apply the violin techniques such as: detache, legato, staccato, spicatto, martelato, sautile, pizzcicato, and others according to learners' need. The techniques and variations of established rhythm can be adjusted to the repertoire they want to play to support repertoire. Gradually learners can increase their tempo to a desired maximum speed.

Practicing pattern using the scale as described above is good warming for coordination between cognition and motor neurons. Learners exercise at least one rung each day. After learners have good results, learners can try to practice using another rung the next day or week. The scales once learned must be practiced consistently even with shorter duration so will gradually become embedded in a long-term memory of learners.

The second stage of the method of Perstude Lahap is the etude. Etude merupakan "komposisi musik yang dipersiapkan dengan tujuan untuk melatih keterampilan mermainankan alat musik" (Banoe, 2003). The etude consists of technical etude intended to practice finger skills and melodic etude to practice reading the signs of expression, articulation and interpretation. Generally, the melodic etude is simple although some have high technical difficulty. Through this etude, learners are required to be able to interpret simple etude to be rich with timbre and impress the listener.

Many of the etudes have been created by previous composers and are still relevant to use to this day. The already available book of etude is recommended for violin learners such as wolhfart 12, kayser 1-2, f mazas, kreuzer, pollo, sevcik, schradieck and so on.

Etude is useful for a violinist to raise his level of playing. The problem that learners often face is impatience in the practice of etude that is perceived to be boring and rushing into song repertoire. There are also some learners who are merely practicing without understanding the concept and desired purpose of the etude. To overcome that, in the method of Perstude Lahap a learner must practice the etude of the instruction book a teacher has suggested and then analyze the purpose of the etude being played. In addition to this, search for alternatives that can be developed from etude trained by such means as detache, legato, spiccato, retrograde and so on.

By daily practice of etude, the violinist will increase in the primavista reading notations. That advantage will help him to learn new repertoire more quickly. While the practice of reading the etude with various variations of friction as well as the technique of play will help the violinist to adapt to the friction and articulation technique that the devoator hopes to join in a musical and orchestra. That makes it easier for learners to coordinate 
between the right hand and the left hand properly. So, it is hoped that gradually it will create a reflective movement, as if the fingers of the left hand had eyes capable of seeing the notes being written and playing them well.

The third stage to go through after learners have played the etude in this mode of Perstude Lahap is to practice the song or repertoire of music. The repertoire often used as the standard study material for violin instruments are the already existing forms of music such as sonata, concerto, suita, and small songs. At this stage learners must first analyze the synopsis, characteristics, and structure of repertoire that will be played.

Learners are invited to seek out and understand about the background of the repertoire that is being played. This is necessary for a proper repertoire, so that the message of music is transmitted in harmony with the dreams of its composer. For example, when about to play the work of johan Sebastian Bach, then characters from the baroque era must appear in playing the music. Learners are required to display the seemingly nimble, light, and use of ornamentation signs conformity with the baroque era.

Most violin learners put only technical side to play but still lack extensive musical knowledge. That lead to a poor interpretation. As an example, the repertoire which should have been played according to the character of the baroque era but in its execution was played with the character of a different era. Teachers must lead learners to become accustomed to searching for complete information about a repertoire that will be playing and encouraging learner's self-reliance gradually.

After learning and understanding about the background, synopsis, and the repertoire of songs that will be played, the next step is the practice of the repertoire material. For example, when learners will play sonata-shaped repertoire, then in practice must be done gradually, such as from the side of the exposure first. At that stage learners will play a repertoire in a slow tempo. Read the notations correctly, find a comfortable sorting position, and produce the right intonation into the focus of this stage. After the above can be properly mastered, the learner focuses on techniques on playing the violin both involving the right hand and the left. Learners must give more training portions for areas with high levels of difficulty. High levels of difficulty included not only the violin technique but also the correct timbre and frasering.
After training the well-exposed part, learners can analyze the next part, which is development. Learners can discover what changes are found in this section. Having been able to analyze, learners can train development parts in the same pattern as when training the exposition section, which is by providing more exercise for those parts that are felt has a high level of difficulty. The same pattern was also used to cultivate the recapitulation of the entire musical work to be properly played. Likewise, the additional forms of the repertoire, such as the concerto and the short songs, require gradual, patterne exercises.

The next step after a piece of music can be well mastered (including pitch, rhythm, and techniques), then violin learners can stress about song interpetation. An interpretation of a piece of music can begin by looking for the message implied in the composition. The last stage of the method of Perstude Lahap is memorization. Memorizing lengthy musical works is not an easy thing for a learner to do. The challenge that learners often face is a lapse in concentration, breaking up wellprepared displays. To avoid them, learners can practice concentration in memorizing each section gradually. The exercise can begin from dividing musical works into several small sections like phrases, then increasing into periods and so on.

Memorizing music is a closely related activity with senses. A learner must be able to analyze habits that are best suited for him, such as memorizing by listening first or by reading visually. Learners with an auditory learning style, memorizing a piece of music by constantly repeating the work into sections. Afterward they could play the musical by accompaniment MIDI or minus one. Meanwhile, learners who have visual learning styles, in memorizing musical works by giving a variety of different markers or colors in each section to be memorized. The goal is to stimulate his mind with such signs.

\section{CONCLUSION}

Based on the results of discussions, it can be concluded that the study of violin instruments can be successful when learners have good intellect or intelligence, strong motivation, a consistent workout that is maintained, and use appropriate methods. The method of Perstude Lahap is one effective alternative to use for learners because they can teach structured training patterns and prompt learners to further develop themselves both cognitive and motor. The method of thoughtfulness 
should be applied to learners who already have middle-to advanced skills so that the results will be more effective. Constant practice of this method of learning can increase creativity in solving problems that can be faced in violin study and find solutions that are relevant to the challenge at hand.

\section{REFERENCES}

Ahmadi, A. (2013). Psikologi Belajar. Jakarta: Rineka Cipta.

Banoe, P. (2003). Kamus Musik Cetakan ke 1. Yogyakarta: PT Kanisius.

Borg, W. R. (2013). Educational Research : An Introduction Seventh Edition. Boston: Heinle-heinle Publisher.

Djamarah, S. B. (2008). Psikologi Belajar. Jakarta: Rineka Cipta.

Fletcher, P. (1987). Education and Music. New York: Oxford Univercity Press.

Psikologi, U. (2018). Definisi Ahli, Sejarah, dan Faktor yang Mempengaruhi Intelegensi. https://www.universitaspsikologi.com/20 18/04/definisi-sejarah-faktormempengaruhi-inteligensi.html

Suzuki, S. (1983). Nurture by Love. USA: Suzuki Method International.Summy Birchard. 
Leo Agung Rupiyono / Jurnal Seni Musik (9) (1) 